\title{
ENTREPRENEURIAL CULTURE OF SPORTS BUSINESS
}

\author{
A. B. Ilyin \\ Bauman Moscow State Technical University, Moscow, Russia \\ e-mail: ilandeducation@yandex.ru
}

\section{Yu. S. Sizova}

Plekhanov Russian University of Economics, Moscow, Russia e-mail: Sizova.YS@rea.ru

\begin{abstract}
Currently, in connection with the development trend of spectacular entrepreneurship, business entities maximize their own profit by scaling up business ideas based on the entrepreneurial event core. In the sports industry, for example, there are plenty of such events: football matches, hockey leagues, car competitions (Formula 1, Formula 2, Formula 3, Formula E). However, aspects of commercialization and monetization often do not coincide with the moral and ethical principles of sports and athletes themselves. As a result, discussion points arise that are on the verge of business and sports. This problem determined the research topic, its goals and results.

The aim of the article is to highlight the principles of the entrepreneurial culture of the sports business based on the determination of the moral and ethical aspects of socially oriented activities of sports organizations.

The following methods were used such as the methodological apparatus of the study: initial models of economic science; organization life cycle theory; theory of entrepreneurial culture.

The main results of the study are as follows: the concept of entrepreneurial culture is defined; $3 M$ levels of its development in the economy are highlighted; presents the relationship of the life cycle of organizations with the sports industry; The principles of entrepreneurial plasticity of the sports business are highlighted; examples of sports ethics of the sports business are given.

For the first time in the theory of business economics, the category of "entrepreneurial plasticity» has been singled out, by which the authors understand the function of a business in responding to key moral and ethical principles of entrepreneurial and socially oriented activities, their preservation, compliance, adaptation and scaling.

The results of the study can be used by entrepreneurial structures of the sports industry.

Key words: entrepreneurship, business economics, entrepreneurial culture, entertaining business, sports business, entrepreneurial plasticity.

Cite as: Ilyin, A. B., Sizova, Yu. S. (2020) [Entrepreneurial culture of sports business]. Intellekt. Innovatsii. Investitsii [Intellect. Innovations. Investments]. Vol. 4, pp. 45-51. DOI: 10.25198/2077-7175-2020-4-45.
\end{abstract}

\section{ПРЕДПРИНИМАТЕЛЬСКАЯ КУЛЬТУРА СПОРТИВНОГО БИЗНЕСА}

\section{А. Б. Ильин}

Московский государственный технический университет имени Н. Э. Баумана, Москва, Россия e-mail: ilandeducation@yandex.ru

\section{Ю. С. Сизова}

Российский экономический университет имени Г.В. Плеханова, Москва, Россия e-mail: Sizova.YS@rea.ru

Аннотация. В настоящее время в связи с тенденцией развития зрелищного предпринимательства хозяйствующие субъекты максимизируют собственную прибыль за счет масштабирования бизнесидей, основанных на предпринимательском ивент-ядре. В отрасли спорта, например, таких мероприятий предостаточно: футбольныле матчи, хоккейные лиги, автомобильньле соревнования («Формула-1», «Формула-2», «Формула-3», «Формула-Е»). Однако аспекты коммерииализаџии и монетизаџии часто не совпадают с моральными и этическими принципами спорта и самих спортсменов. Как следствие возникают дискуссионные моменты, находящиеся на грани бизнеса и спорта. Данная проблема определила тему исследования, его цели и результатьл. 
Целью статьи являетсявыделение принщипов предпринимательской культуры спортивного бизнеса на основе определения моральных и этических аспектов социально ориентированной деятельности спортивных организаций.

В качестве методического аппарата исследования использованы следующие методы: исходные модели экономической науки; теории жизненных цииклов организации; теории предпринимательской культуры.

Основные результаты исследования заключены в следующем: определено понятие предпринимательской культуры; выделень 3М уровни ее развития в экономике; представлено соотношение жизненного цикла организаций со спортивной отраслью; выделены принщипы предпринимательской пластичности спортивного бизнеса; приведены примеры спортивной этики спортивного бизнеса.

Впервые в теории экономики предпринимательства выделена категория «предпринимательская пластичность», под которой авторы понимают функиию бизнеса по реагированию на ключевые моральные и этические принщипь предпринимательски- и сочииальноориентированных видов деятельности, их сохранение, соблюдение, адаптаџию и масштабирование.

Результаты исследования могут быть использованы предпринимательскими структурами спортивной отрасли.

Ключевые слова: предпринимательство, экономика предпринимательства, предпринимательская культура, зрелищное предпринимательство, спортивный бизнес, предпринимательская пластичность.

Для цитирования: Ilyin, A. B., Sizova, Yu. S. (2020) [Entrepreneurial culture of sports business]. Intellekt. Innovatsii. Investitsii [Intellect. Innovations. Investments]. Vol. 4, pp. 45-51. DOI: 10.25198/2077-7175-2020-4-45.

\section{Introduction}

The industry of physical culture and sports over the past few years has received an impetus for rapid development due to an increase in demand for spectacular sports events, sports services and goods. In addition, the fashion for a healthy lifestyle, the desire of the population for physical and spiritual development create the prerequisites for obtaining additional sources of income in the sports industry and creating jobs, providing the interconnection between the sports and near sports spheres of activity. The degree of developing of the sports industry has an impact on the pace of socioeconomic development of society, the quality and living standard of citizens, business activity in the country.

The main trend of modern sports organizations is their full or partial commercialization, a turn towards entrepreneurial activity, and the social orientation of these organizations, in turn, makes it possible to diversify their activities as much as possible. Implementation of a commercial component in sports has provoked changes in almost all areas of sport activities. In addition to the formation of a large number of sports business entities of various legal forms (fitness clubs, health clubs, sections for various sports, etc.), commerce has been introduced into professional sports and in the field of organizing sports events, servicing their participants, attracting sponsors to their organization, advertising, and also has been created the global sports entrepreneurial structures.

\section{Discussion}

Since there are currently sports organizations acting as independent business units, they obey the objective laws of the business environment and they compete in their market segment.

The competitiveness of these organizations can be achieved both at the expense of their economic poten- tial, and through the development of an entrepreneurial culture, formed at the micro, meso- and macro- levels of economic development.

The work of such foreign researchers as W. Andreft, J. Bourge, M. Brooks, B. Mullin, S. Rice, M. Tomich, K. Hempek, G. Hogg, F. Schaaf and others is devoted to the development of sports organizations.

As for Russian researchers, the development of the sports industry as a whole is devoted to work (A. V. Selivanenko, A. V. Tukmanova, O. V. Tsygankova, T. V. Yurievaand etc.,) and the entrepreneurial aspect of sports business units is consecrated in the works of modern authors: S. V. Altukhov, A. B. Ilyin [8], L. N. Orlova, S. A. Ostroukhov [11].

It should be noted that in the process of analyzing economic literature, the authors revealed that the issues of establishing entrepreneurship in the field of sports are widely discussed; forms and types of entrepreneurship in this area; pricing and the formation of supply and demand for sporting goods / services; sports marketing and management; competitiveness of sports organizations. However, the theme of developing the entrepreneurial culture of sports organizations is not covered as business unit.

Entrepreneurial culture is an integral element of the business organization. There are various approaches to the definition of the concept of "entrepreneurial culture" both in foreign studies and in the works of Russian economists.

The study of the essence and elements of entrepreneurial culture is devoted to the research of Russian and foreign experts, such as L. Ya. Averyanov [1], A. I. Ageev [2], S. Begelsdeyk [4], F. Braudel, E. N. Vasilieva [5], M. Weber [16], M. A. Volkova [6], P. S. Gurevich, V. P. Dudyashova, K. David, B. S. Erasov, P. V. Zhuravlev [7], N. S. Zlobin, L. Kolesnikova, A. L. Kuzevanova, L. S. Leontieva[9], 
M. S. Lapitsky, P. Levy [10], V. V. Radaev, R. Ryvkina, R. Ruttinger [12], Yu. S. Sizova, O. K. Slinkova [13], O. V. Sokolov, V. A. Spivak, W. Terpstra [14], F. Trompenaars [15], Ch. Hampden-Turner, V. I. Cherenkov.

It is worth noting that by the end of the 20th century, interest in the culture of entrepreneurship increased due to the fact that entrepreneurship became the main source of income for the middle class.

For example, the following interpretation of the concept of «entrepreneurial culture» belongs to M. G. Lapusta, who considered it as «a certain, established set of principles, techniques, methods of entrepreneurial activity entities in accordance with legal norms in the country, business practices, ethical and moral rules, standards of conduct in the implementation of a civilized business. After all, the entrepreneurial culture is exposed to a plurality of external influences such as accepted business standards, political environment, legislation, state control, economic factors, competition, business support infrastructure technology» [9].

According to the authors of this study, the entrepreneurial culture of business units develops or degrades under the influence of many factors: changes in the business activities of the business unit, the characteristics of the business environment and government influence.
Yu. Sizova refers to a set of elements aimed at creating a business environment with a favorable culture with the aim of forming business activity at the micro- (level of the business entity), mezo- (between partners / contractors) and the macro level (at the state level): at the macro level (national level) - support for business entities, including institutional mechanisms and infrastructure elements; at the mesoscale (intercompany infrastructure of entrepreneurship and at the regional level) - the creation of favorable conditions and the fulfillment of obligations in order to create an active business environment; At the micro level (of an economic entity), an entrepreneurial culture will contribute to improving the quality of products and services, developing production efficiency, and, consequently, increasing entrepreneurial income [9].

In its turn, sport appeared in the middle of the XIX century as a form of entertainment for children of English aristocrats. Since, it has scaled up from the enthusiastic competition into a commercialized business project involving such stakeholders as TV, sponsors, and advertisers. Professional sport has become an industry with a huge market.

Since today sports organizations are considered as business entities, the development levels of their entrepreneurial culture will correspond to the level of other business units and are presented in Figure 1 and grouped according to the $3 \mathrm{M}$ principle.

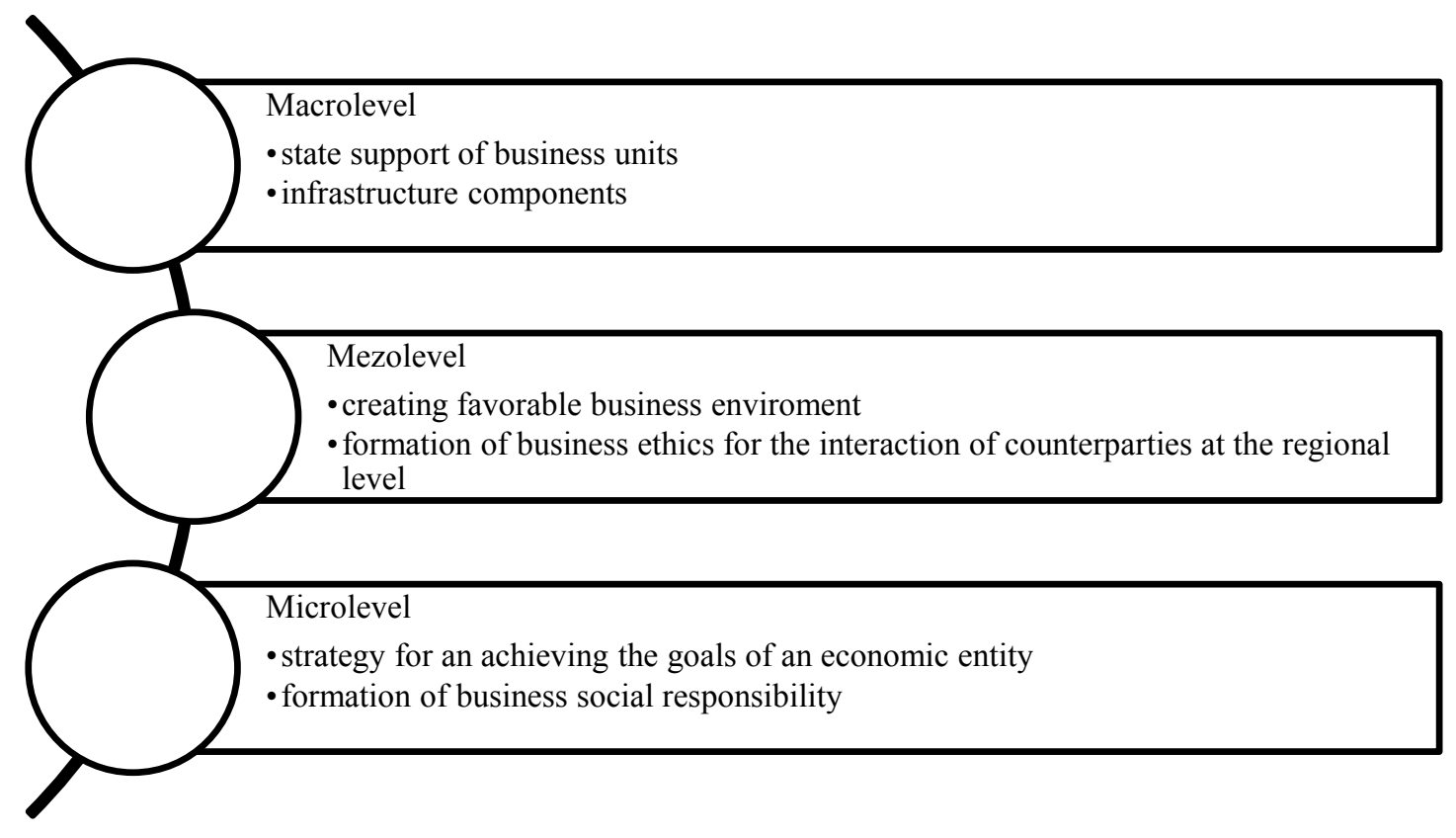

Figure 1. Levels of entrepreneurial culture development Source: compiled by the authors.

In addition to the $3 \mathrm{M}$ levels of formation of an entrepreneurial culture, an economic entity, including a sports organization, passes certain stages oflife cycle.

The management theory describes several models, as, for example, A. Down, «Driving Forces of Growth» (1967); G. Lippitt and W. Schmidt «Management Participation» (1967); B. Scott «Strategy and Structure» (1971); L. Greiner «Problems of leadership 
at the stages of Evolution and Revolution» (1972); W. Torbert «The mentality of the organization members» (1974); D. Katz and R. Kahn «Organizational structure» (1978); I. Adizes «Theory of organizational life cycles» (1979).

According to I. Adizes [3] the development of a business unit is presented as a process involving the passage's certain stages of the life cycle that cannot be avoided or skipped.

His theory, based on the two most important parameters of the organization's life - flexibility and controllability, formed the basis of a unified life cycle model for a sports organization engaged in commercial activities, as shown in Figure 2.



Figure 2. Unified model of the life cycle sports organization

Source: compiled by the authors

Entrepreneurial culture finds its development vectors at each stage of the life cycle sports organization through $3 \mathrm{M}$ prism. However, the determining component of the sport does not affect in any way and does not depend on the life stages of the business, since sport, fulfilling its social function, has high entrepreneurial plasticity. It is primarily subject to the principles of sports ethics, and not to the principles of business. Further, the authors highlighted the principles of entrepreneurial plasticity sports organization.

\section{Principles of Entrepreneurial Plasticity of Sports Organizations}

By entrepreneurial plasticity, the authors understand the function of a business in responding to key moral and ethical principles of entrepreneurial socially oriented activities, their preservation, compliance, adaptation and scaling.

The principles of entrepreneurial plasticity of sports organizations:

- since sports organizations perform a social function, the formation of social responsibility of sports business units to society occurs at all stages of the life cycle (birth, growth, maturity, decreased activity, the termination of the sports business);
- despite the increase in the sports business entertainment, the moral and ethical principles of sports and athletes must be respected;

- the sports stakeholders (state, society, MM) 3M levels should not interfere with sports ethics;

- the sports business needs close interaction with sectoral institutional structures, inter-sectoral complexes of enterprises and organizations;

- business management models, regulatory procedures and the legal framework of sports should not contradict the ethics of sports and athletes;

- the culture consumption of sports merchandise is responsible for emphasizing sports aspects;

- the sports business should be included in the hierarchy of state interests;

- the model decentralization of anti-doping regulation in world sport should not demoralize the sports business;

- the sports business is responsible for maintaining the values of sports in a changing global world;

- the sports business should not be focused only on the capitalization of bookmakers;

- sport is responsible for being a means, not a goal, of changing basic sport values and ethical regulation of the industry.

So, the global company Formula One is primarily an 
entrepreneurial structure. The entrepreneurial income of the organization is formed by the sale of spectator tickets to the race tracks, the organizational fees of the race tracks for the right to conduct competitions on its territory, the realization of television rights to broadcast competitions, sponsors and others. Various discussion intersections of the entrepreneurial plasticity of the sports business with sports ethics ended with the thesis that Formula One is a business, not a sport. For example:

- racer Jaime Alguersuari criticized the modern Formula One in 2020: «Formula One is rather business, than sport. Racers are no longer employees, by which the team attract new sponsors»; ${ }^{1}$

- later, in 2014, racer Jacques Villeneuve said: «I do not consider, that Formula One is an extreme sport, because there are too many restrictions in the driver's natural instincts.» ${ }^{2}$;

- Fernando Alonso, after a penalty for blocking an opponent on the track in 2006: «My problem is solved. I tried to drive the circle as fast as possible, and, obviously, I did not block anyone. I respect the fans who gathered at the circuit, but I do not consider Formula 1

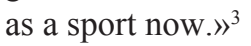

Obviously, the example of «Formula 1» is not unique. Politics interference in sports, athlete's disqualification in personal interests, doping scandals, the demoralization of sports and athletes in the MM are examples of non-compliance with the principles of entrepreneurial plasticity or the lack of an entrepreneurial culture of sports.

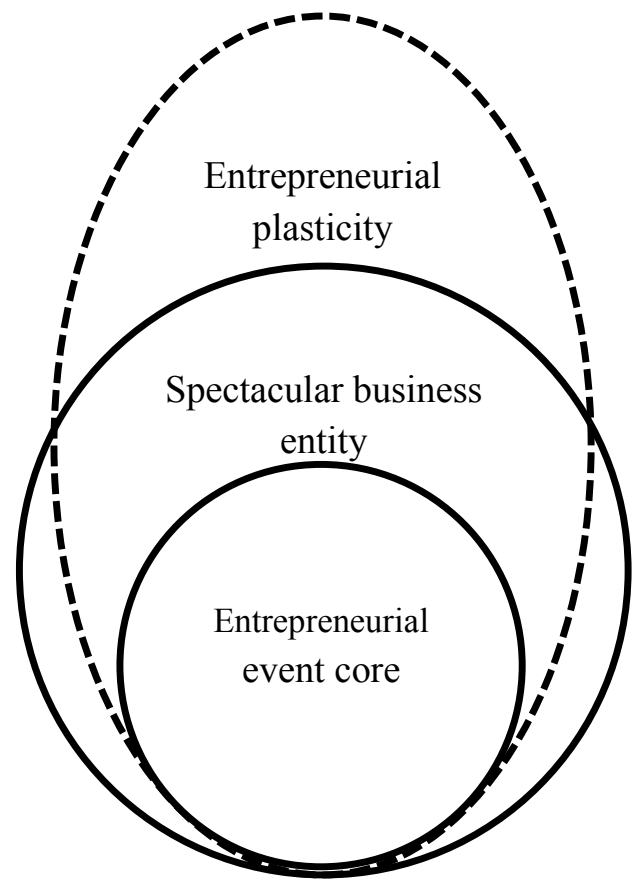

Figure 3. Entrepreneurial plasticity of the sports business

Source: compiled by the authors.

Figure 3 shows that entrepreneurial plasticity as a function of business is directly related to the essence of the spectacular entrepreneurship subject (the entrepreneurial core).The event core is unique business idea on the basis of which is built a commercially viable organization project. In addition, entrepreneurial plasticity goes beyond the framework of the entrepreneurial structure, since the formation of moral and ethical principles occur under the influence of external stakeholders. The principles of entrepreneurial plasticity sports organizations presented by the authors indicate that these include government agencies, public organizations, the MM, various business units, other sports organizations, athletes at the macro-, mezo- and micro- levels of economic development.

Former pilot Toro Rosso "Formula One is not a sport, but a business". Availed at: https://www.sport-express.ru/autosport/formula1/ news/byvshiy-pilot-toro-rosso-formula-1-eto-ne-sport-a-biznes-1638507/.

2 Jacques Villeneuve 2No longer, I consider Formula 1 as an extreme sport» Availed at: https://www.sports.ru/automoto/1022356176. html.

3 Fernando Alonso «I don’t consider Formula One as a sport» Availed at: https://www.flnews.ru/news/ f1-14738.html. 


\section{Conclusion}

Entrepreneurial culture has importance in the direct activity of an economic entity, and in its interaction with other business entities, authorities at all levels of economic development. However, the formation and observance of an entrepreneurial culture have particular importance in socially significant sectors such as culture, education, and sports. As the authors showed, entrepreneurialoriented organizations of this type are responsible for maintaining, observing, adapting and scaling entrepreneurial plasticity. It (plasticity) involves the business response to key moral and ethical principles specific to the industry. In particular, for the sports business it is very important to maintain sports ethics, sports values, moral and ethical principles of athletes. In turn, the trend of spectacular entrepreneurship has led to the demoralization of sports based on the principles of commercialization and monetization. The event component of the sporting event, sports betting, sports merchandising began to come to the fore.

The authors also conclude, that entrepreneurial culture finds its development vectors at each stage of the organization's life cycle through the prism of $3 \mathrm{M}$ (macro-, mezzo- and micro- level).However, as the sport performs a social function, the determining component of the sport does not affect in any way and does not depend on the life stages of the business. Thus, the entrepreneurial culture of the sports business has specific approaches, and the organizations themselves are socially responsible for its accumulation, adaptability and additivity.

\section{References}

1. Averjyanov, L. Ya. (2001) Organizatsionnaya kul'tura upravleniya sovremennykh predprinimatel'skikh struktur [Organizational culture of managing modern business entities]. Moscow, $29 \mathrm{p}$.

2. Agejev,A.I. (2016) Predprinimatel'stvo: monografiya [Entrepreneurship: monograph]. Moscow:Institution of Economic Strategies, RUBIN. 536 p.

3. Adizes, I. (2007) Upravleniye zhiznennym tsiklom korporatsii [Management of the life cycle corporation]. According to the scientific edit. A. G. Seferyan. St. Petersburg: Peter, 384 p.

4. Begelsdijk, S. (2016) Kul'tura v ekonomicheskoy nauke: istoriya, metodologicheskiye rassuzhdeniya $i$ oblasti prakticheskogo primeneniya $v$ sovremennosti [Culture in economics: history, methodological considerations and practical application areas in modern times]. Moscow; St. Petersburg: Publishing House of the Gaidar Institute, 464 p.

5. Vasiljeva, E. N. (2008) Formirovaniye kul 'tury predprinimatel 'stva v sovremennoy Rossii: institutsional'nyy i funktsional'nyy aspekty [The formation of entrepreneurial culture in Modern Russia: institutional and functional aspects]. «Printerra», $160 \mathrm{p}$.

6. Volkova, M. F. (2011) Organizatsionnaya kul'tura v menedzhmente znaniy: monografiya [Organizational culture in knowledge management] Kostroma: Publishing house KSTU, 168 p.

7. Zhuravljev, P. V. (2015) [The influence of mental models on the development and overhauling of national economies]. Vestnik Rossiyskogo ekonomicheskogo universiteta im. G. V. Plekhanova [Herald of the Plekhanov Russian University of Economics]. Vol. 1 (79), pp. 82-89. (In Russ.).

8. Ilyin, A. B. (2019) [Evaluation activities of the global company "Formula-1" in the CIS countries using specific methods of formal logic]. Intellekt. Innovatsii. Investitsii [Intellect. Innovations. Investments]. Vol. 7, pp. 36-42 (In Russ.).

9. Leontjeva, L. S., Sizova, Y. S. (2016) [Entrepreneurial Culture: Essence And Items]. Mezhdunarodnyy nauchno-issledovatel'skiy zhurnal [International Research Journal]. Vol. 12-5 (54), pp. 161-165. (In Russ.).

10. Levy P. (2006) Korporativnaya kul'tura $i$ upravleniye izmeneniyami [Corporate Culture and Change Management]. Moscow: Alpina Business Books, 192 p.

11. Ostroukhov, S. A. (2017) [Entrepreneurship in sports or how is formed competitiveness of sports organizations]. Rossiyskoye predprinimatel'stvo [Russian Entrepreneurship]. Vol. 1, No. 3, pp. $405-416$ (In Russ.).

12. Ruttinger, R. (1992) Kul'tura predprinimatel'stva [Entrepreneurship culture]. Moscow: ECOM, 240 p. (In Russ., trans. from Dutch).

13. Slinkova, O. K. (2009) [Organizational culture management]. Vestnik YUUrGU [Herald of SUNU]. Issue: Economics and Management. Vol. 21, pp. 64-74. (In Russ.).

14. Terpstra, V., David, K. (1991) The Cultural Environment of International Business. South-Western Publishing Co., Cincinnati, OH. 252 p.

15. Trompenaars, F., Hampden-Turner, Ch. (2000) Riding the Waves of Culture: Understanding Cultural Diversity in Business. Nicolas Brealey Publishing, London. 265 p.

16. Weber, M. (1975) The Spirit of Capitalism and Protestant Ethics. Moscow, 220 p. 
Information about the authors:

Andrei Borisovich Ilin, Ph.D in Economics, Associate Professor, Department of Innovative Entrepreneurship, Bauman Moscow State Technical University, Moscow, Russia

ORCID ID: 0000-0002-4055-1814, Researcher ID: M-5928-2016

e-mail: ilandeducation@yandex.ru

Yulia Sergeevna Sizova, Ph.D in Economics, Associate Professor, The Humanitarian Training Center, Plekhanov Russian University of Economics, Moscow, Russia

ORCID ID: 0000-002-7760-6436

e-mail: Sizova.YS@rea.ru,ju-si@mail.ru

The paper was submitted: 17.03.2020.

Accepted for publication: 17.06.2020.

The authors have read and approved the final manuscript.

Информация об авторах:

Андрей Борисович Ильин, кандидат экономических наук, доцент кафедры инновационного предпринимательства, Московский государственный технический университет имени Н.Э. Баумана, Москва, Россия

ORCID ID: 0000-0002-4055-1814, Researcher ID: M-5928-2016

e-mail: ilandeducation@yandex.ru

Юлия Сергеевна Сизова, кандидат экономических наук, доцент Центра гуманитарной подготовки, РЭУ имени Г.В. Плеханова, Москва, Россия

ORCID ID: 0000-002-7760-6436

e-mail: Sizova.YS@rea.ru,ju-si@mail.ru

Статья поступила в редакцию: 17.03.2020; принята в печать: 17.06.2020.

Авторы прочитали и одобрили окончательный вариант рукописи. 